Article

\title{
Trends and Variability of AVHRR-Derived NPP in India
}

\section{Govindasamy Bala ${ }^{1, *}$, Jaideep Joshi ${ }^{2}$, Rajiv K. Chaturvedi ${ }^{3}$, Hosahalli V. Gangamani ${ }^{1}$, Hirofumi Hashimoto ${ }^{4}$ and Rama Nemani ${ }^{4}$}

1 Divecha Center for Climate Change and Center for Atmospheric and Oceanic Sciences, Indian Institute of Science, Bangalore 560012, India; E-Mail: gangahv@gmail.com

2 Centre for Ecological Sciences, Indian Institute of Science, Bangalore 560012, India;

E-Mail: jaideep777@gmail.com

3 Centre for Sustainable Technologies, Indian Institute of Science, Bangalore 560012, India;

E-Mail: chaturvedi.rajiv@gmail.com

4 NASA Ames Research Center, Moffett Field, CA 94035, USA;

E-Mails: hirofumi.hashimoto@gmail.com (H.H.); rama.nemani@nasa.gov (R.N.)

* Author to whom correspondence should be addressed; E-Mail: gbala@caos.iisc.ernet.in; Tel.: +91-802-293-3428; Fax: +91-802-293-3425.

Received: 1 December 2012; in revised form: 10 January 2013 / Accepted: 14 January 2013 / Published: 15 February 2013

\begin{abstract}
In this paper, we estimate the trends and variability in Advanced Very High Resolution Radiometer (AVHRR)-derived terrestrial net primary productivity (NPP) over India for the period 1982-2006. We find an increasing trend of 3.9\% per decade $(r=0.78$, $\mathrm{R}^{2}=0.61$ ) during the analysis period. A multivariate linear regression of NPP with temperature, precipitation, atmospheric $\mathrm{CO}_{2}$ concentration, soil water and surface solar radiation $\left(\mathrm{r}=0.80, \mathrm{R}^{2}=0.65\right)$ indicates that the increasing trend is partly driven by increasing atmospheric $\mathrm{CO}_{2}$ concentration and the consequent $\mathrm{CO}_{2}$ fertilization of the ecosystems. However, human interventions may have also played a key role in the NPP increase: non-forest NPP growth is largely driven by increases in irrigated area and fertilizer use, while forest NPP is influenced by plantation and forest conservation programs. A similar multivariate regression of interannual NPP anomalies with temperature, precipitation, soil water, solar radiation and $\mathrm{CO}_{2}$ anomalies suggests that the interannual variability in NPP is primarily driven by precipitation and temperature variability. Mean seasonal NPP is largest during post-monsoon and lowest during the pre-monsoon period, thereby indicating the importance of soil moisture for vegetation productivity.
\end{abstract}


Keywords: AVHRR-derived NPP; vegetation productivity; $\mathrm{CO}_{2}$ fertilization; afforestation; soil water; atmospheric $\mathrm{CO}_{2}$

\section{Introduction}

Terrestrial net primary productivity (NPP) is one of the most important ecosystem variables that have been studied extensively during the last 40 years [1]. It is a fundamental ecological variable, not only because it measures the terrestrial carbon dioxide assimilation, but it also indicates the type (e.g., crops, forests) of the land surface area and status of a wide range of ecological processes. Practical considerations for estimating NPP exist in its utility to measure crop yield, forest productivity and other economically and socially significant products of vegetation origin. Determining the trend and variability of terrestrial NPP and its response to climate change is critical for understanding the potential carbon cycle changes in response to temperature, precipitation and other factors such as $\mathrm{CO}_{2}$ fertilization.

Modern ecology relies heavily on experiments, both in laboratory and in field settings. However, true global measurements could only be made using satellite remote sensing which provides large sample sizes. Global ecosystem models provide the basis for computing a satellite-based estimate of NPP. These models range from simple ones based on light use efficiency (LUE) to more mechanistic models based on "Soil-Vegetation-Atmospheric-Transfer" (SVAT) schemes designed to capture variability in biospheric processes.

LUE-based models are less complex and easily use remotely sensed data and map primary productivity of the terrestrial biosphere over large areas. Satellite data-driven LUE models such as C-Fix [2], Carnegie-AMES-Stanford-Approach (CASA) [3], Global Production Efficiency Model (GLO-PEM) [4], Simple Diagnostic Biosphere Model (SDBM) [5], Terrestrial Uptake and Release of Carbon (TURC) [6] and Moderate Resolution Imaging Spectroradiometer (MODIS) NPP algorithm [7-9] have been developed to produce spatiotemporal pattern of NPP over continents or global land surface. Estimates of daily gross primary productivity (GPP) and annual net primary productivity (NPP) at the $1-\mathrm{km}$ spatial resolution are now produced operationally for the global terrestrial surface using imagery fromthe MODIS sensor [9]. NPP products can also be derived from process-based SVAT schemes [10].

Investigation of vegetation responses to climatic changes using climatic data and satellite observations of vegetation activity for 1982-1999 [8] indicated that the global NPP increased by 6\% (3.4 peta grams of carbon ( $\mathrm{PgC})$ over 18 years). The largest increase was in tropical ecosystems where Amazon rain forests accounted for $42 \%$ of the global increase, owing mainly to decreased cloud cover and the resulting increase in solar radiation [8]. In qualitative agreement with these results, using satellite observation and the GLO-PEM model for 1981-2000, an increasing trend in terrestrial NPP that was superimposed on large seasonal and interannual variations was found in another study [11]. However, estimates for the recent period 2000-2009 [12] suggest a reduction in the global NPP of $0.55 \mathrm{PgC}$. Large-scale droughts have been cited as the likely cause during this period. A drying trend in the southern hemisphere was found to be associated with a decreased NPP in that area which counteracted the increased NPP in the northern hemisphere. 
Estimates of NPP for India vary widely depending on the observational data and the terrestrial carbon cycle model used. For 1980, the annual NPP is estimated at $1.24 \mathrm{PgC}$, based on observed carbon inventory data in various ecosystems [13]; for the mid-eighties, it is approximately $1.32-1.59 \operatorname{PgC~[14].~}$ Another study [15], using 10-day global NDVI (Normalized Difference Vegetation Index) composites along with C-Fix model for June 1998-May 1999 has estimated a value of $2.18 \mathrm{PgC}$. The estimate of NPP for India using the CASA model is $1.57 \mathrm{PgC}$ for 2003, which is slightly higher than the estimates by the C-Fix (1.45 PgC) and MODIS NPP algorithms (1.30 PgC) for the same period [16]. A more recent work [17] used NOAA-AVHRR satellite data and the GLO-PEM model for 1981-2000 and obtained much higher values between 3.56 (1983) and $4.57 \mathrm{PgC}$ (1998). This recent work showed a positive trend of approximately $8.5 \%$ increase per decade in NPP. A CASA model based study for the period 1981-2006 [18] finds that the NPP increased by about $8.5 \%$ during this 25 -year period, primarily due to enhancement in agricultural productivity; the climate had a relatively small role $(15 \%)$.

In this paper, we investigate the trends and variability of AVHRR (Advanced Very High Resolution Radiometer)-derived NPP over India. Specifically, we focus on the linear trend and interannual and seasonal variability in NPP for the period 1982-2006. Multivariate regression is used to understand the causes for the trends and interannual and seasonal variability in NPP. The NPP data that we use here is different from data that have been used in the past. Investigations using different datasets and methods help to identify the robustness and uncertainty in earlier results. For instance, we find trends similar to past studies, but our results on interannual variability linking NPP and ENSO are not in agreement with earlier studies.

\section{Data}

The study area is India, which is a large country with a total geographical area of 329 million ha. It is located between $7^{\circ}$ and $40^{\circ} \mathrm{N}$ and between $68^{\circ}$ and $100^{\circ} \mathrm{E}$. India experiences climatically four distinct seasons: southwest summer monsoon (June to August), northeast winter monsoon (December to February), spring or pre-monsoon (March to May) and autumn post-monsoon (September to November) inter-monsoonal periods. The southwest monsoon is essentially warm and humid, and the rainfall received during this period accounts for about $80 \%$ of the total annual rainfall of the country. The NE monsoon is cold and dry; however, southeastern parts of the country receive significant rainfall during this period. The two inter-monsoonal periods are mostly dry and moderately warm.

The NPP estimates make use of vegetation greenness observations from the AVHRR [19] in conjunction with a light use efficiency model implemented for the MODIS sensor [9]. The algorithm uses fraction of absorbed photosynthetically active radiation (fPAR) and leaf area index (LAI) derived using AVHRR NDVI and radiative transfer models [20]. Satellite data from multiple AVHRR sensors have been processed consistently, accounting for differences and drift in calibration among the sensors, as well as atmospheric effects from ozone and water vapor. Climate drivers are from the National Center for Environmental Prediction reanalysis. The LUE algorithm first generates an estimate of potential GPP as a function of fPAR, incident radiation and biome specific radiation use efficiencies. Subsequently, the potential GPP is down regulated using daily temperature and soil moisture constraints. An autotrophic respiration component, sum of maintenance and growth components, is 
computed separately using air temperature, seasonally adjusted Q10 and carbon pools (leaf, root and stem) derived from the satellite-derived LAI.

The Normalized Difference Vegetation Index (NDVI) used in the retrieval of our NPP product has been used recently to document the stagnation of food production in water-limited regions of the tropics [21].It was also used to characterize year-to-year variations in vegetation dynamics in Central Asia [22], to study the trends and variability in vegetation structure in a grassland in Canada [23], and to examine vegetation change for a range of agricultural systems in Inner Mongolia, China [24]. The algorithm (called MODIS algorithm) used to obtain our NPP dataset has been validated using Ameriflux data from North America [25], Bigfoot data for North America and Brazil at nine sites representing a range of biomes [26], and global Ecosystem Model-Date Intercomparison (EMDI) NPP dataset [7]. GPP from MODIS algorithm has been also validated for a mixed forest site in the Nepalese Himalayas [27]. These validation studies have indicated that the NPP product used here are reliable. Further, our NPP dataset has been found to represent interannual variability in climate-driven vegetation activity reasonably well $[8,9]$.

The climate data (temperature and precipitation) at a resolution of $0.5^{\circ}$ are obtained from Climatic Research Unit (CRU) (www.cru.uea.ac.uk/cru/data/hrg) at the University of East Anglia (UEA). The global annual mean of atmospheric $\mathrm{CO}_{2}$ is obtained from NOAA/ESRL (National Oceanic and Atmospheric Administration/Earth System Research Laboratory) databases (www.esrl.noaa.gov/gmd/ ccgg/trends/). The soil moisture data for the top $3.4 \mathrm{~m}$ soil (http://hydro1.sci.gsfc.nasa.gov/dods/), Global Land Data Assimilation System (GLADS), were acquired as part of the mission of NASA's Earth Science Division and archived and distributed by the Goddard Earth Sciences (GES) through the Data and Information Services Center (DISC). Though GLADS has datasets from multiple land models, we used the $1^{\circ}$ dataset from offline Community Land Model (CLM2) which has the largest number of soil layers [10] for a total soil depth of $3.4 \mathrm{~m}$. The downward solar radiation at the surface is obtained from MERRA (Modern-Era Retrospective Analysis for Research and Applications) data (http://gmao.gsfc.nasa.gov/merra) Version 5.2.0 of the GEOS-5 DAS (Data Assimilation System) at $1 / 2 \times 2 / 3$ degrees resolution. Sea surface temperature (SST) anomalies for the Nino3 region (Nino3-SST) are obtained from the CPC (Climate Prediction Centre), NOAA (http://www.cpc.noaa.gov/data/ indices/sstoi.indices). The Multivariate Enso Index (MEI) for characterizing ENSO is obtained from http://www.esr/noaa.gov/psd/enso/mei.ext. Net irrigated area and fertilizer consumption data is obtained from the Department of Agriculture and co-operation, Government of India (http://eands.dacnet.nic.in/latest_2006.htm). Forest plantation and afforestation statistics are obtained from the Ministry of Environment and Forests, Government of India (http://envfor.nic.in/nfap/ table-geographic-area.html\#plantation) [28].

\section{Results}

\subsection{Mean and Variance}

The mean NPP and standard deviation over the period (1982-2006) in India are estimated at $0.83 \mathrm{PgC} \cdot \mathrm{y}^{-1}$ and $0.03 \mathrm{PgC} \cdot \mathrm{y}^{-1}$ which are less than the CASA-model estimate of $1.42 \mathrm{PgC} \cdot \mathrm{y}^{-1}$ and $0.06 \mathrm{PgC} \cdot \mathrm{y}^{-1}$ for $1981-2006$ [18]. The mean and standard deviations are 0.79 and $0.02 \mathrm{PgC} \cdot \mathrm{y}^{-1}$, 
respectively, when the linear trend is removed. Since all available global scale NPP products are model based, it is important to recognize that trends and variability estimated from these products are likely more reliable and consistent than the mean values. As can be seen from Figure 1(a), NPP shows a large spatial variation across the country with high values $\left(\sim 800 \mathrm{gC} \cdot \mathrm{m}^{-2} \cdot \mathrm{y}^{-1}\right)$ in northeast India, parts of the Western Ghats and the Himalayan forests. Low values are observed in dry regions, such as northwest India, and areas of the western and northernmost parts of India. The spatial pattern of standard deviation (Figure 1(b)) resembles the mean NPP: the absolute magnitude of variation is higher where the mean is higher. It varies from 0 in low-productivity regions to as high as $40 \mathrm{gC} \cdot \mathrm{m}^{-2} \cdot \mathrm{y}^{-1}$ in high productivity regions. However, the coefficient of variation $(\mathrm{CV})$ which is the standard deviation normalized by mean NPP shows high values in regions with low productivity (Figure 1(d)). The spatial pattern of AVHRR-derived NPP, standard deviation and CV are similar to that simulated by the CASA-model [18].

Figure 1. Spatial pattern of (a) annual mean, (b) standard deviation, (c) temporal evolution of domain-mean NPP, (d) coefficient of variation of NPP, (e) spatial pattern of the annual NPP trends, and (f) percentage decadal trends of NPP from 1982 to 2006.
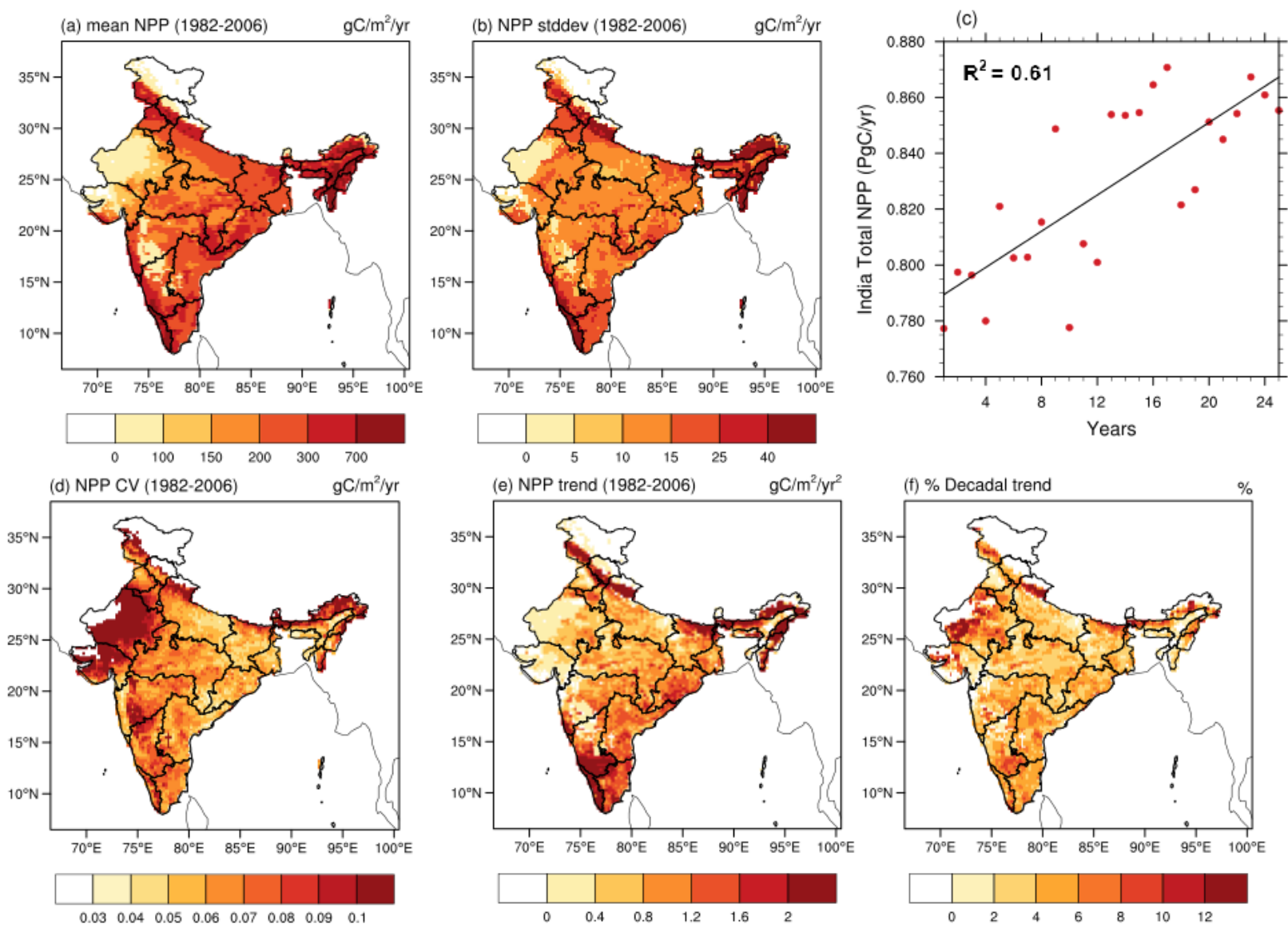

\subsection{Trends in NPP}

NPP has an increasing temporal trend as seen in Figure 1(c). We will denote the correlation coefficient as " $r$ " and the coefficient of determination which is the fraction of variability explained by a linear regression model as " $\mathrm{R}$ ", The total NPP over the country increased from $0.78 \mathrm{PgC} \cdot \mathrm{y}^{-1}$ in 1982 to $0.86 \mathrm{PgC} \cdot \mathrm{y}^{-1}$ in 2006 . The increase is consistent with the spatial pattern presented in [8], which 
shows an increase in NPP from 1982 to 1999. The linear growth rate estimate suggests a positive trend of $0.39 \%$ per year during the analysis period $\left(r=0.78, \mathrm{R}^{2}=0.61\right)$ or $3.9 \%$ per decade, which is in close agreement with the positive trend of $3.5 \%$ per decade obtained from a different dataset [18]. Linear regression was performed for every grid point to obtain the spatial pattern of linear trends (Figure 1(e-f)). Positive trends are observed over the Western Ghats, Himalayan forests in the north, parts of northeast India, central and eastern India. Near-zero or slightly negative trends are observed over parts of the northwest and northernmost parts of India.

To examine the role of temperature, precipitation, atmospheric $\mathrm{CO}_{2}$, soil water in the top $3.4 \mathrm{~m}$ and downward surface solar radiation on the evolution of NPP, we used single and multivariate analysis:

$$
\mathrm{NPP}=\mathrm{C}_{0}+\mathrm{C}_{1} \mathrm{X}_{1}+\mathrm{C}_{2} \mathrm{X}_{2}+\mathrm{C}_{3} \mathrm{X}_{3} \ldots+\mathrm{C}_{\mathrm{N}} \mathrm{X}_{\mathrm{N}}+\mathrm{R}
$$

where $\mathrm{X}_{1}, \mathrm{X}_{2}, \mathrm{X}_{3}, \ldots \mathrm{X}_{\mathrm{N}}$ are the independent variables such as temperature, precipitation, soil water, downward solar radiation at the surface and global-mean atmospheric $\mathrm{CO}_{2}$, and $\mathrm{C}_{0}, \mathrm{C}_{1}, \mathrm{C}_{2}, \ldots \mathrm{C}_{\mathrm{N}}$ are constants, and $\mathrm{R}$ is the residue which represents the nonlinear terms. $\mathrm{N}=1$ for single variable analysis. We have used at most $\mathrm{N}=5$ in this paper. It should be noted that the variables such as temperature and solar radiation, and precipitation and soil water are not truly independent of each other. The NPP time series developed using Equation (1) will be called multivariate NPP and we will be mostly interested in the correlation ( $r$ ) between observed NPP and the multivariate NPP and the $\mathrm{R}^{2}$ values to infer the influence of a single, or a combination of, variables on NPP.

Figure 2(a-i) shows the time evolution of spatially averaged NPP, precipitation, temperature, $\mathrm{CO}_{2}$, surface solar radiation and soil water in the top $3.4 \mathrm{~m}$ in India. The correlation between domain-mean NPP versus precipitation, temperature, $\mathrm{CO}_{2}$, solar radiation and soil moisture are 0.18 , $0.42,0.76,-0.72$, and -0.61 , respectively (Figure 2 , Table 1 ). The corresponding $\mathrm{R}^{2}$ values are 0.03 , $0.18,0.58,0.51$ and 0.37 , respectively (Figure 3, Table 1). This implies that NPP increase is primarily associated with an increase in global mean $\mathrm{CO}_{2}$. The correlations are negative with soil water and solar radiation because these variables have a declining trend while NPP has a positive trend (Figure 2).

Table 1. Correlation coefficient ( $r$ ) between observed NPP and climate variables and multivariate NPP for various cases. $\mathrm{R}^{2}$ (coefficient of determination) values are given in parenthesis. $\mathrm{P}, \mathrm{T}, \mathrm{CO}_{2}, \mathrm{SW}$ and $\mathrm{SR}$ in curly brackets refer to the independent climate variables precipitation, temperature, global mean $\mathrm{CO}_{2}$, soil water in the top $3.4 \mathrm{~m}$ soil and downward solar radiation at the surface, respectively in Equation (1).

\begin{tabular}{|c|c|c|c|c|c|}
\hline $\begin{array}{l}\text { Single Variable } \\
\text { Linear } \\
\text { Regression of } \\
\text { NPP } \\
\end{array}$ & $\begin{array}{l}\text { Multivariate } \\
\text { Regression of } \\
\text { NPP }\end{array}$ & $\begin{array}{c}\text { Single Variable } \\
\text { Regression of } \\
\text { Interannual NPP } \\
\text { Anomaly } \\
\end{array}$ & $\begin{array}{c}\text { Multivariate } \\
\text { Regression of } \\
\text { Interannual NPP } \\
\text { Anomaly } \\
\end{array}$ & $\begin{array}{c}\text { Single Variable } \\
\text { Regression of } \\
\text { Seasonal NPP } \\
\text { Anomaly } \\
\end{array}$ & $\begin{array}{c}\text { Multivariate } \\
\text { Regression of } \\
\text { Seasonal NPP } \\
\text { Anomaly } \\
\end{array}$ \\
\hline $0.18(0.03)\{P\}$ & $0.50(0.25)\{\mathrm{P}$ and $\mathrm{T}\}$ & $0.35(0.12)\{\mathrm{P}\}$ & $0.38(0.14)\{\mathrm{P}$ and $\mathrm{T}\}$ & $0.52(0.27)\{P\}$ & $0.65(0.42)\{\mathrm{P}$ and $\mathrm{T}\}$ \\
\hline $0.42(0.18)\{T\}$ & $\begin{array}{c}0.80(0.63) \\
\left\{\mathrm{P}, \mathrm{T} \text { and } \mathrm{CO}_{2}\right\}\end{array}$ & $-0.22(0.05)\{\mathrm{T}\}$ & $\begin{array}{c}0.48(0.23) \\
\left\{\mathrm{P}, \mathrm{T} \text { and } \mathrm{CO}_{2}\right\}\end{array}$ & $\begin{array}{c}0.01(0.0001) \\
\{\mathrm{T}\}\end{array}$ & $\begin{array}{c}0.95(0.91) \\
\{\mathrm{SW} \text { and } \mathrm{SR}\}\end{array}$ \\
\hline $0.76(0.58)\left\{\mathrm{CO}_{2}\right\}$ & $\begin{array}{c}0.80(0.64) \\
\left\{\mathrm{P}, \mathrm{T}, \mathrm{CO}_{2} \text { and } \mathrm{SW}\right\}\end{array}$ & $\begin{array}{c}-0.27(0.07) \\
\left\{\mathrm{CO}_{2}\right\}\end{array}$ & $\begin{array}{c}0.49(0.23) \\
\left\{\mathrm{P}, \mathrm{T}, \mathrm{CO}_{2} \text { and } \mathrm{SW}\right\}\end{array}$ & $0.95(0.90)\{\mathrm{SW}\}$ & $\begin{array}{c}0.98(0.96) \\
\{\mathrm{P}, \mathrm{T} \text { and } \mathrm{SW}\}\end{array}$ \\
\hline$-0.61(0.37)\{S W\}$ & $\begin{array}{c}0.80(0.65) \\
\left\{\mathrm{P}, \mathrm{T}, \mathrm{CO}_{2}, \mathrm{SW} \text { and }\right. \\
\mathrm{SR}\}\end{array}$ & $0.24(0.06)\{\mathrm{SW}\}$ & $\begin{array}{c}0.56(0.31) \\
\left\{\mathrm{P}, \mathrm{T}, \mathrm{CO}_{2}, \mathrm{SW} \text { and }\right. \\
\mathrm{SR}\}\end{array}$ & $\begin{array}{c}-0.63(0.40) \\
\{\mathrm{SR}\}\end{array}$ & $\begin{array}{c}0.98(0.96) \\
\{\mathrm{P}, \mathrm{T}, \mathrm{SW} \text { and } \mathrm{SR}\}\end{array}$ \\
\hline$-0.72(0.51)\{\mathrm{SR}\}$ & & $\begin{array}{c}-0.23(0.05) \\
\{\mathrm{SR}\}\end{array}$ & & & \\
\hline
\end{tabular}


Figure 2. Temporal evolutions of domain-averaged NPP and (a) temperature, (b) and precipitation, (c) global-mean atmospheric $\mathrm{CO}_{2}$, (d) downward solar radiation at the surface and (e) soil moisture in the top $3.4 \mathrm{~m}$ soil for 1982-2006. Panels $(\mathbf{f}-\mathbf{j})$ are similar to (a-e) except the variables are now interannual anomalies (i.e., mean and trends are removed from the original data). In each panel, the correlation ( $r$ ) between the two time series is also shown.
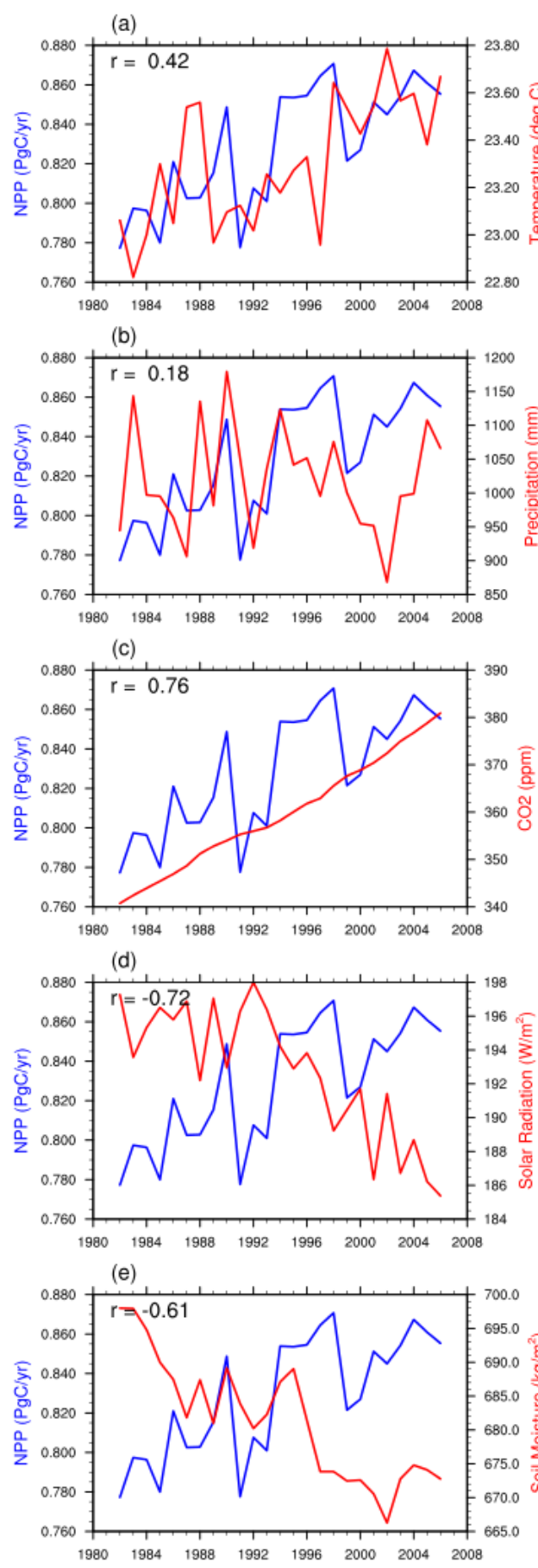
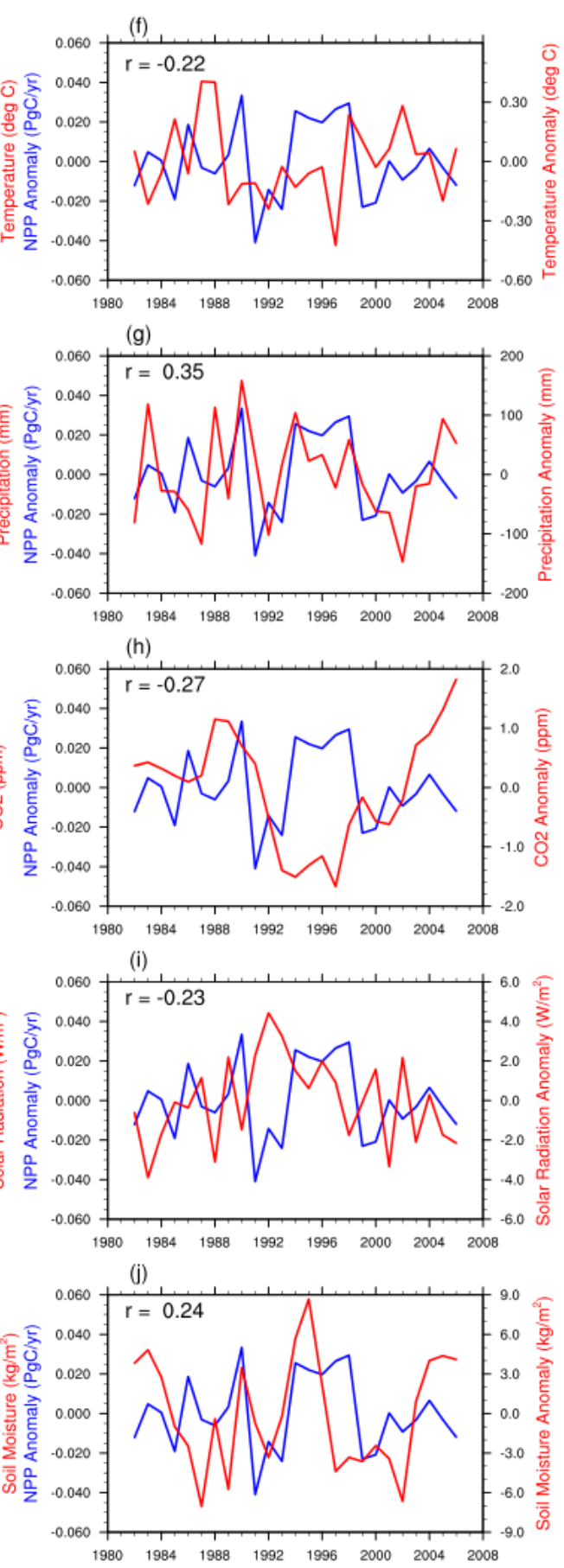

We caution that a statistical analysis like this cannot establish firm casual relationships and thus we cannot make robust attribution statements. Recently, it was found that the increase in NPP in India is mainly contributed by enhancements in cropland areas [18]. Therefore, it is possible that land use 
management practices may have also played an important role in NPP increase. We discuss in detail the role of land use management practices on NPP increase in forest and non-forest areas in Section 3.5.

When precipitation and temperature are used as independent variables in Equation (1), the correlation between the observed and multivariate NPP is 0.50 and $\mathrm{R}^{2}$ is 0.25 (Figure 3, Table 1) which indicates that a combination of temperature and precipitation have a stronger control on NPP than either precipitation or temperature individually. The correlation and $\mathrm{R}^{2}$ increase to 0.80 and 0.63 , respectively (Figure 3, Table 1) when multivariate NPP is generated from precipitation, temperature and $\mathrm{CO}_{2}$ confirming the stronger relationship between observed NPP and $\mathrm{CO}_{2}$. The correlation and $\mathrm{R}^{2}$ do not increase any further when soil water and surface solar radiation are used in the multivariate regression (Table 1).

Figure 3. Scatter plots between the annual-mean observed NPP over India and (a) temperature, (b) precipitation, (c) $\mathrm{CO}_{2}$ concentration, (d) multivariate NPP using precipitation and temperature as independent variables and (e) multivariate NPP using precipitation, temperature and $\mathrm{CO}_{2}$ as independent variables. Panels $(\mathbf{f}-\mathbf{j})$ are similar to (a-e) except that the variables NPP, temperature, precipitation and $\mathrm{CO}_{2}$ are interannual anomalies (the linear trends are removed from the original data). In each panel, $\mathrm{R}^{2}$ (coefficient of determination) values for the regression model is also shown.
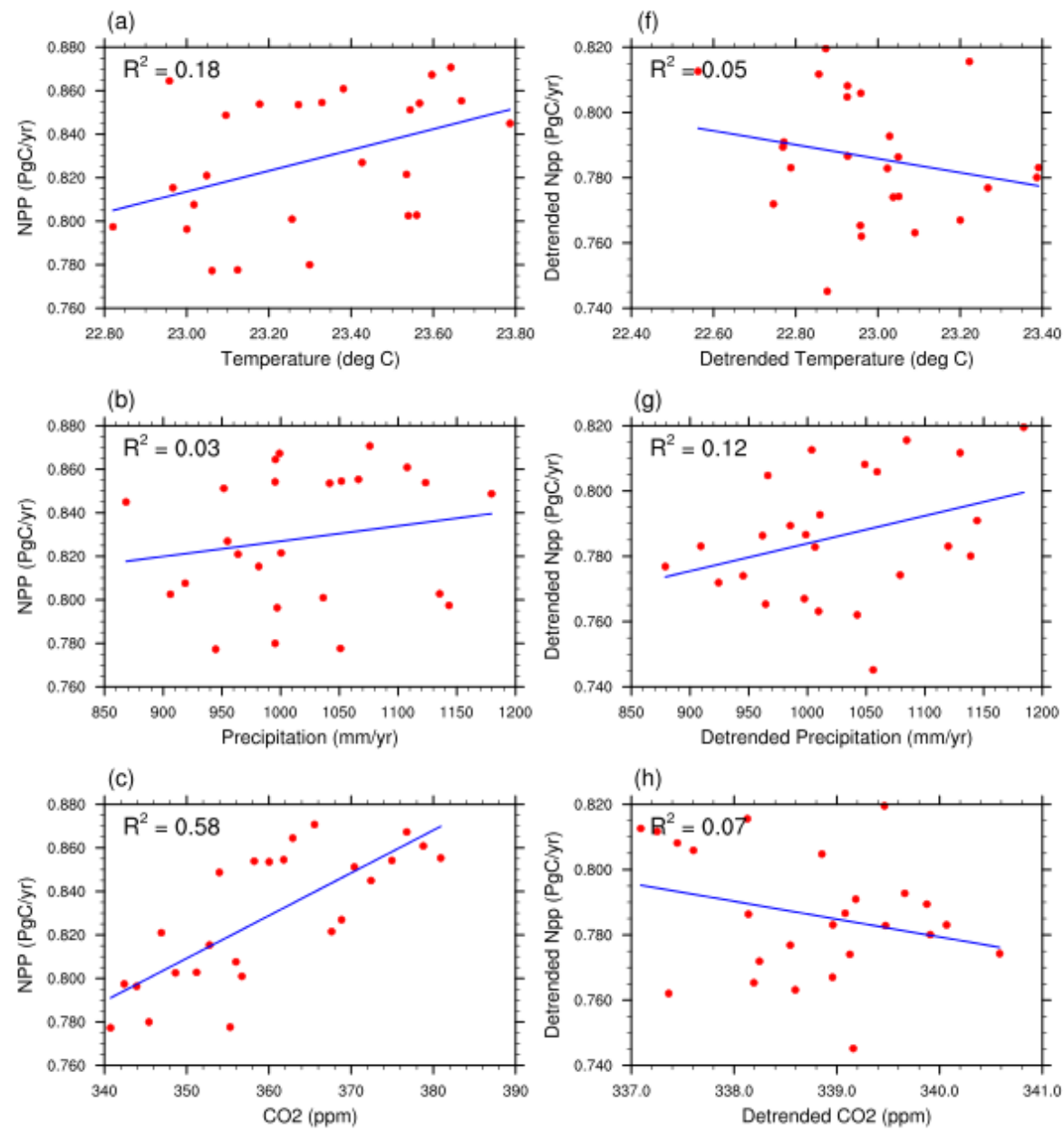
Figure 3. Cont.
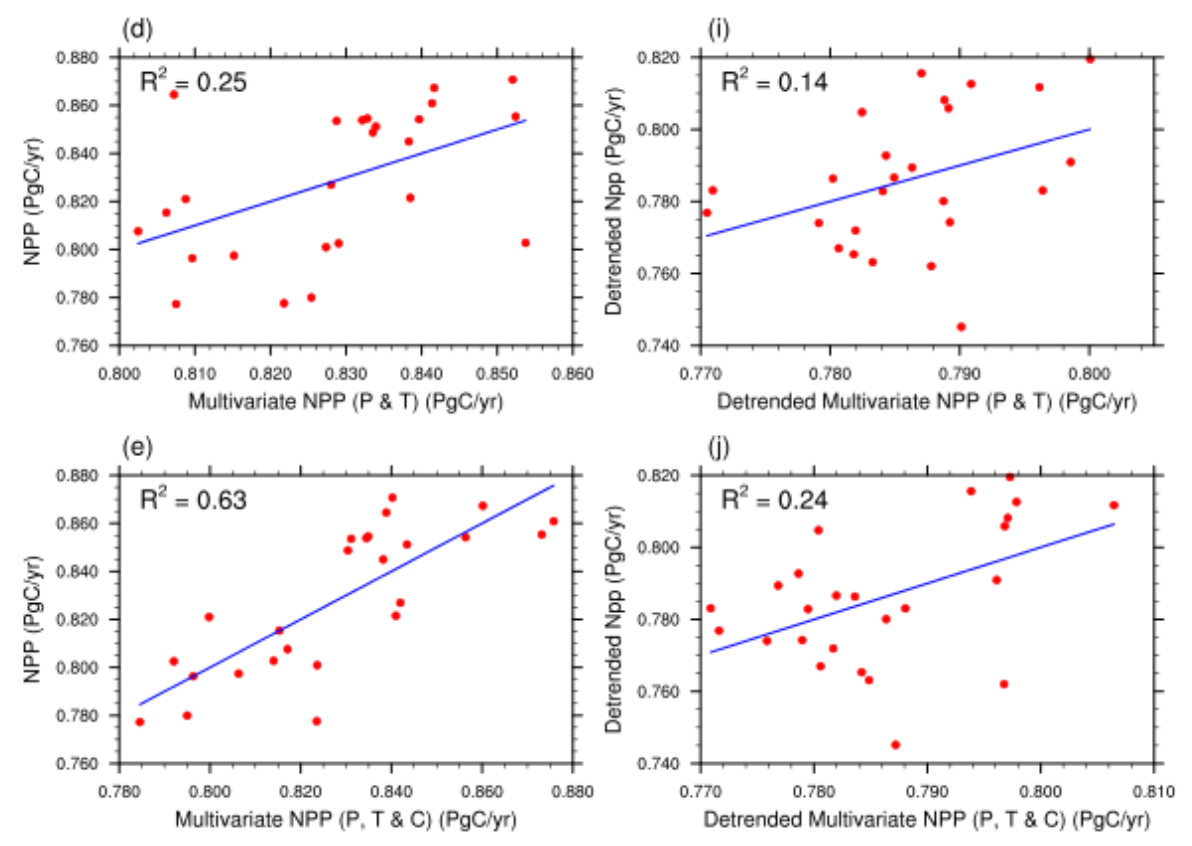

Over all, this analysis indicates that increasing atmospheric $\mathrm{CO}_{2}$ is probably the main driver for the positive trend in NPP, although other causes such as land use change cannot be ruled out. In the absence of other limiting factors, increasing atmospheric $\mathrm{CO}_{2}$ concentration has the potential to stimulate photosynthesis (or Gross Primary Productivity when scaled up) and, hence, NPP. This is an effect known as $\mathrm{CO}_{2}$ fertilization [24,29,30]. Experimental studies provide evidence for $\mathrm{CO}_{2}$ fertilization: for example, free-air $\mathrm{CO}_{2}$ enrichment experiments in forest stands show $23 \%$ median increase in NPP for a $\mathrm{CO}_{2}$ change from 376 to $550 \mathrm{ppm}$ [31]. Long-term tree ring studies suggest a more complex picture and perhaps a lack of universality of the $\mathrm{CO}_{2}$-fertilization effect [32].

Coupled climate-carbon models all show increases in terrestrial carbon uptake as a result of $\mathrm{CO}_{2}$ fertilization [33-36]). In a recent paper, the bounds on terrestrial carbon uptake over India that arises solely due to $\mathrm{CO}_{2}$ fertilization were investigated [37]. It was found that NPP increased by $84 \%$ solely due to $\mathrm{CO}_{2}$ fertilization by the year 2100 relative to 1975 and decreased by $13 \%$ due to climate change for the SRES A2 emissions scenario. Since the $\mathrm{CO}_{2}$-fertilization effect was about 4 to 5 times stronger than climate effect in that modeling study, the net effect was an enhancement in NPP by about $71 \%$ between 2100 and 1975 .

Global carbon budgets studies have also indicated that the global land is a sink for carbon [38,39]: in spite of deforestation in the tropics, about $20 \%-25 \%$ of the fossil emissions have been taken up by land in past decades. Therefore, it is likely, as shown by our analysis, that $\mathrm{CO}_{2}$ fertilization is the main driver for the increase in NPP in India and also, possibly, for the positive trend in global mean NPP [8]. More research is needed to find out the extent to which $\mathrm{CO}_{2}$ fertilization is responsible for present terrestrial carbon uptake and potential future terrestrial ecosystem carbon sink.

\subsection{Interannual Variability in NPP}

Past studies have indicated that the interannual variability of terrestrial NPP over different parts of the globe have been related strongly to the interannual variability of climatic parameters $[8,40]$. The 
spatial pattern of correlation between observed NPP and precipitation and NPP and temperature (Figure 4(a,b)) shows that NPP has a positive correlation with precipitation almost everywhere except in the Himalayan forest region in the north and negative correlation with temperature except in central eastern India and the Himalayan forest areas. The correlation shown in Figure 4(a,b) has contributions from correlations in trend and variability. In order to show only the contribution from variability, we subtract the trends before calculating the correlations (Figure $4(\mathrm{c}, \mathrm{d})$ ). Correlation with temperature is negative for temperature in most regions (Figure 4(c)). The spatial pattern of correlation between NPP and precipitation in Figure 4(d) is in good agreement with a recent study [18] which concluded that there is a significantly large correlation between NPP and precipitation. Our results are also similar to the findings by another study [11] which concluded that interannual variations in NPP are positively correlated with precipitation and negatively with temperature everywhere except high latitudes $\left(>50^{\circ} \mathrm{N}\right)$ where NPP is enhanced by warming. The spatial pattern of the temperature trend over India from 1982 to 1999 also indicates negative correlation with the NPP trend (negative temperature trend in Figure 1 and positive NPP trend in Figure 2 in [8]).

Figure 4. Correlation of NPP with (a) temperature and (b) precipitation. Correlation of interannual NPP anomaly (trend and mean removed) with (c) temperature anomaly and (d) precipitation anomaly.

(a) NPP $\ll->$ Temp

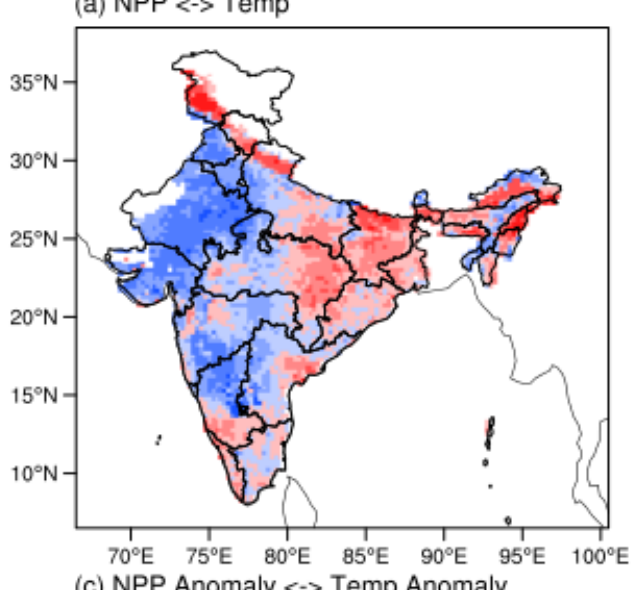

(c) NPP Anomaly $\leftrightarrow$ Temp Anomaly

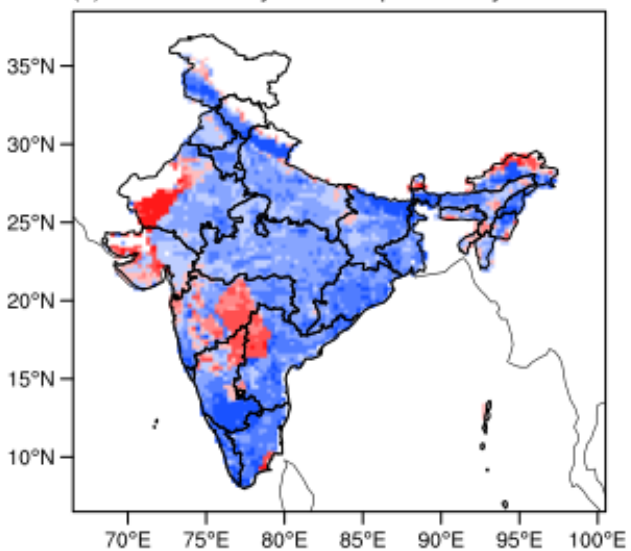

(b) NPP $<->$ Precip

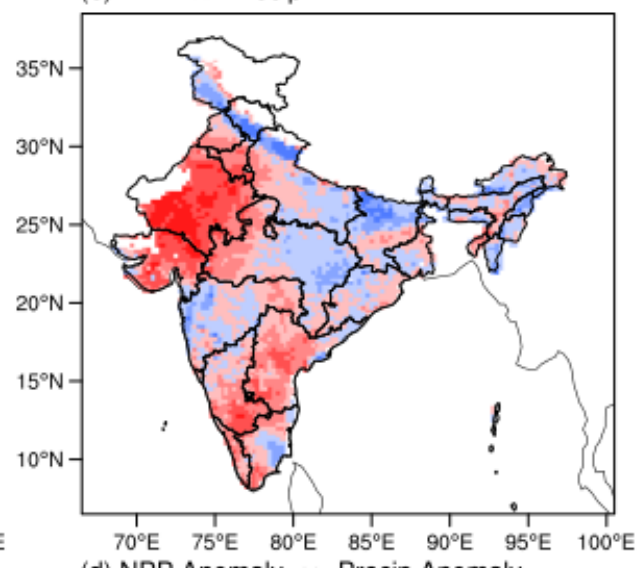

(d) NPP Anomaly $<->$ Precip Anomaly

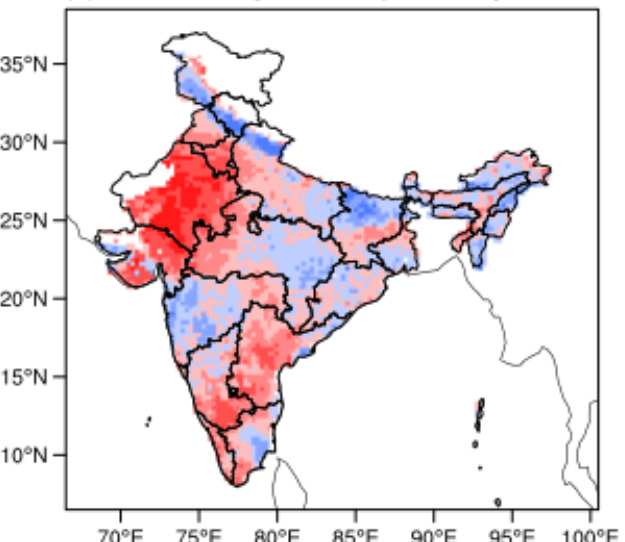

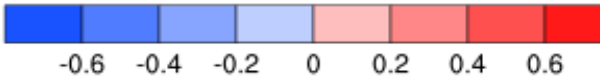


In order to cleanly separate interannual variability from the effects of trends, we subtracted the linear trend and mean from the observed time series of annual mean NPP, precipitation, temperature, soil water, solar radiation in India and global mean $\mathrm{CO}_{2}$ to create interannual anomalies. The correlation and multivariate analysis is subsequently performed on these anomalies (Figures 2 and 3 ). We find that the correlation between observed NPP and precipitation anomalies is $0.35\left(\mathrm{R}^{2}=0.12\right)$ but the correlation is only $-0.22\left(\mathrm{R}^{2}=0.05\right)$ between NPP and temperature anomalies (Figure 3; Table 1). This analysis clearly indicates that the interannual variations in NPP are positively correlated with precipitation and negatively but weakly with temperature. The correlation between NPP and $\mathrm{CO}_{2}$ anomalies is also weak and negative at $-0.27\left(\mathrm{R}^{2}=0.07\right)$ which suggests that interannual variations in NPP are inversely correlated to interannual variations in global mean $\mathrm{CO}_{2}$. While the correlation with soil water is positive (Figure $2(\mathrm{j}) ; \mathrm{r}=0.24 ; \mathrm{R}^{2}=0.06$ ), the correlation with solar radiation (Figure 2(i); $r=-0.23, R^{2}=0.05$ ) has the same sign as with temperature (Figure $2(f) ; r=-0.22 ; R^{2}=0.05$ ), thus indicating the dependence of temperature on solar radiation.

The correlation between NPP and multivariate anomaly is $0.38\left(\mathrm{R}^{2}=0.14\right)$ when the multivariate NPP anomaly is created using precipitation and temperature as independent variables (Table 1 and Figure 3). The correlation increases to $0.48\left(\mathrm{R}^{2}=0.23\right)$ when $\mathrm{CO}_{2}$ is also included as an independent variable along with precipitation and temperature (Table 1).The correlation increases marginally when soil water $\left(r=0.49, R^{2}=0.23\right)$ is added and further when solar radiation is added $\left(r=0.56, R^{2}=0.31\right)$. The main inference on the interannual anomalies is that precipitation variability is the main driver for interannual variations in NPP in India since precipitation anomaly has the largest correlation with NPP anomaly in the single variable regression analysis (Table 1).

There have been indications from earlier studies that regional NPP over India is also controlled by remote events such as ENSO. For instance, negative NPP anomaly during El Nino and positive anomaly during La Nino have been shown by recent studies [11,18]. Specifically, it is found that NPP declined during the recent four major ENSO events (1982-1983, 1987-1988, 1997-1998 and 2002-2003) [18]. Further, it has been also shown that NPP in India is inversely correlated to atmospheric $\mathrm{CO}_{2}$ growth rate anomalies [18]. On a global scale, reduced terrestrial carbon uptake during ENSO leads to larger growth rates of atmospheric $\mathrm{CO}_{2}$, although terrestrial NPP accounts for only part of the biosphere-atmosphere carbon exchange $[8,11]$. However, it is not clear if the relationship between global NPP, global atmospheric $\mathrm{CO}_{2}$, and ENSO would be unchanged when we consider NPP only over India.

In Figure 5(a), we show the time series of interannual NPP anomaly (trend and mean removed) and $\mathrm{CO}_{2}$ growth rate anomaly for 1982-2006. $\mathrm{CO}_{2}$ growth rate anomaly is calculated as the departure from the averaged $\mathrm{CO}_{2}$ growth rate which is calculated as the difference in $\mathrm{CO}_{2}$ between successive years. In contrast to other studies [18], we find that the NPP anomaly is weakly but positively correlated $\left(\mathrm{r}=0.23, \mathrm{R}^{2}=0.05\right)$ to the $\mathrm{CO}_{2}$ growth rate anomaly. This suggests that the NPP anomaly over India is not in phase with global NPP anomaly. Figure 5(b) shows that the correlation between NPP anomaly and Nino3-SST anomaly is also weak $\left(r=0.14, \mathrm{R}^{2}=0.02\right)$. This result is also in contrast to the recent study [18] which finds declines in NPP during ENSO years (positive Nino3-SST anomaly). The growth in NPP anomaly after the Mount Pinatubo eruption in 1991 (Figure 5) is in agreement with the global study [8]which found that the cooling from the eruption may have promoted plant growth in low latitudes by reducing evapotranspiration and respiration losses. 
Figure 5. Temporal evolutions of interannual NPP anomaly over India and (a) $\mathrm{CO}_{2}$ growth rate anomaly, (b) Nino-3 SST anomaly, and (c) Multivariate ENSO Index (MEI). The right panels show the corresponding scatter plots. The coefficient of correlation (r) and $\mathrm{R}^{2}$ values are also shown.

(a)

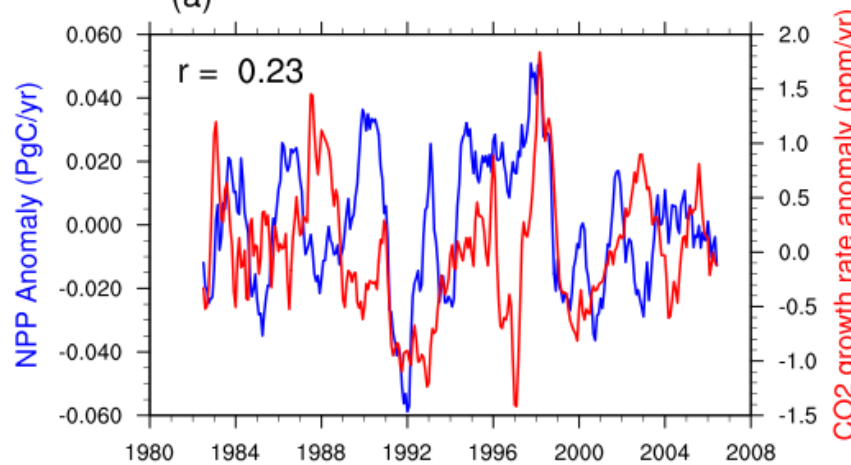

(b)

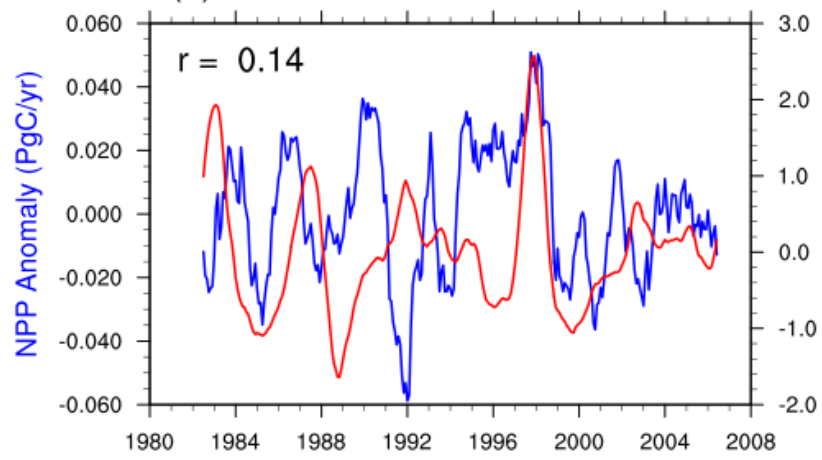

(c)

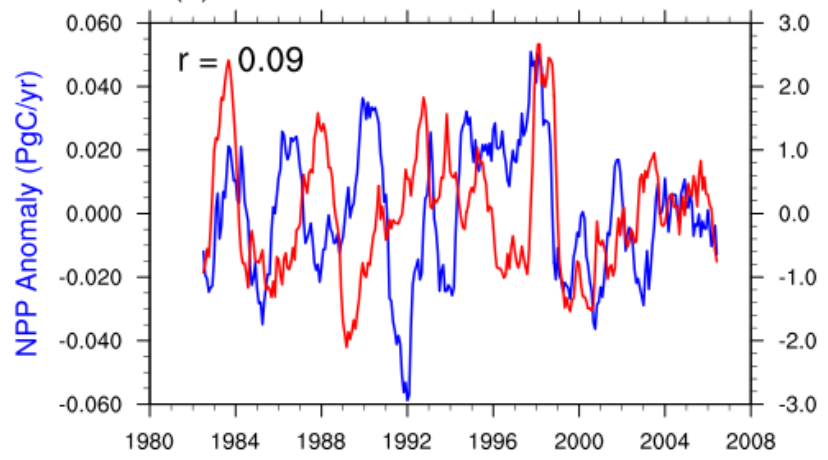

(d)

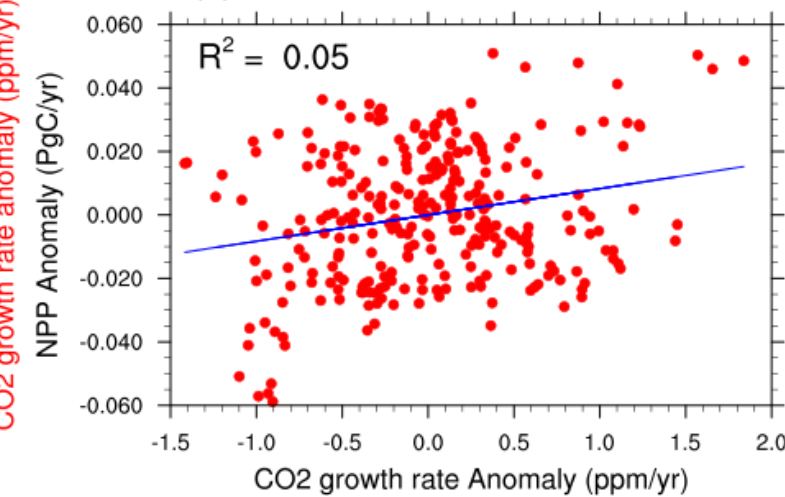

(e)

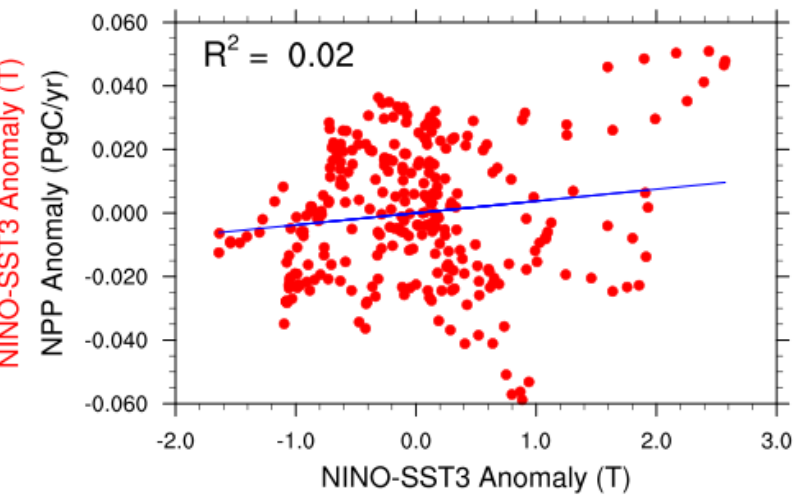

(f)

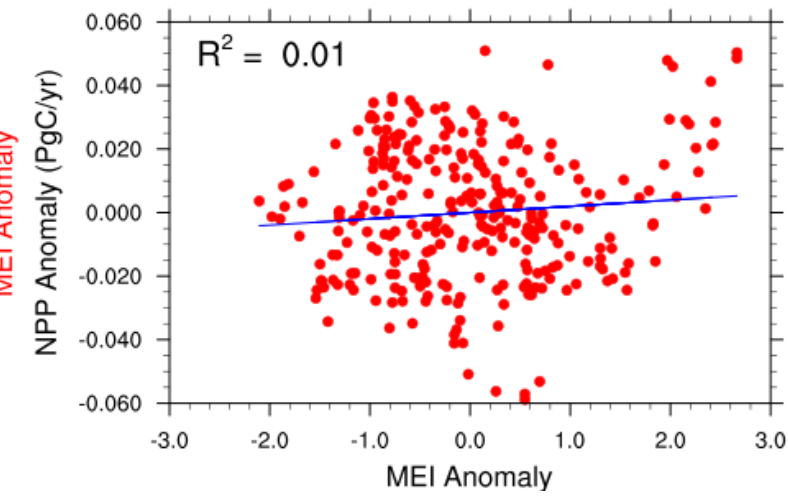

As an alternate to Nino-3 SST index and as in other studies $[8,18]$, we also used the multivariate ENSO index (MEI) as the ENSO index (Figure 5(c)). MEI is the multivariate measure of the ENSO signal as expressed in the first principal component of six observed variables in the tropical Pacific [41]: sea-level pressure, zonal and meridional components of the surface wind, sea surface temperature, surface air temperature, and total cloudiness fraction of the sky. In this case, as well, in contrast to [18], we find the correlation is too low $\left(\mathrm{r}=0.09, \mathrm{R}^{2}=0.01\right)$. In summary, we do not find a strong correlation between the NPP anomaly over India and the $\mathrm{CO}_{2}$ growth rate anomaly, nor between the NPP anomaly and ENSO. The cause for the discrepancy between our results and a previous 
study [18] is not clear to us. Further investigation is required to ascertain the existence or lack of correlation between NPP anomalies and remote events.

\subsection{Seasonal Variability in NPP}

The NPP time series for four seasons corresponding to southwest summer monsoon (June-August), northeast winter monsoon (December to February), spring or pre-monsoon (March-May) and autumn or post-monsoon (September to November) is shown in Figure 6 (top left), and the mean seasonal cycle of NPP and key climate variables are shown in Figure 6 (top right).

We see that the maximum NPP is observed during the post-monsoon period (SON) rather than during summer monsoon season (JJA). NPP reaches minimum value in pre-monsoon period (MAM). The discussion of interannual variations in the previous section would suggest a maximum NPP in JJA when the precipitation reaches the maximum (Figure 6). However, since temperature (which has a negative correlation with NPP) is also high during this period, it is likely to reduce the NPP during JJA. We find that the soil water content is a maximum during SON (Figure 6) which is closely associated with the maximum NPP observed during SON.

Figure 6. Temporal evolutions of domain-averaged seasonal mean NPP for pre-monsoon (MAM), southwest summer monsoon (JJA), post-monsoon (SON) and northeast winter monsoon (DJF) seasons (top left), mean seasonal cycle of NPP, surface temperature, precipitation, solar radiation and soil moisture (top right), and the multivariate NPP estimated using precipitation and temperature as independent variables (blue), soil water and surface solar radiation as independent variables (green), precipitation, temperature and soil water as independent variables (black) and precipitation, temperature, soil water and solar radiation as independent variables (orange; bottom). The correlation coefficient (r) between seasonal NPP anomaly and independent variables are shown in the top right panel. $\mathrm{R}^{2}$ values for the regression between seasonal cycle of NPP and the various multivariate NPP are shown in bottom panel.
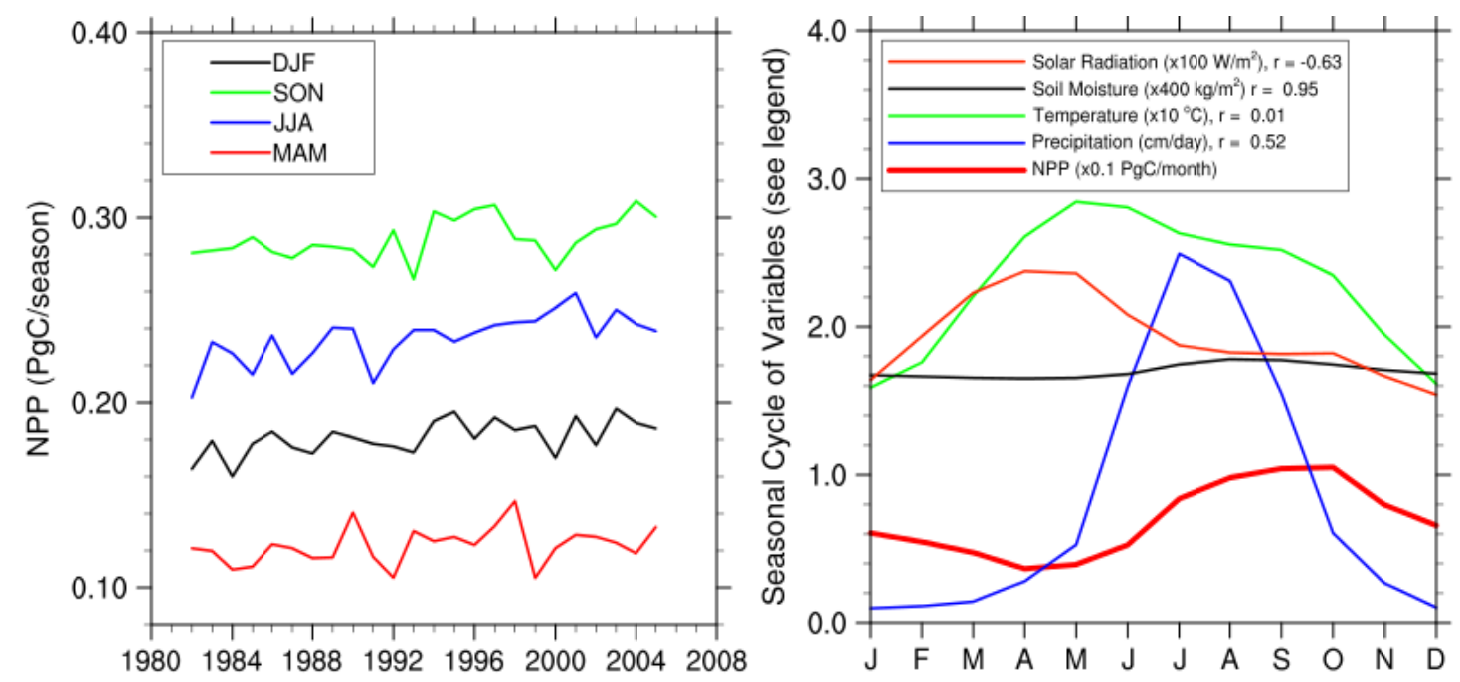
Figure 6. Cont.

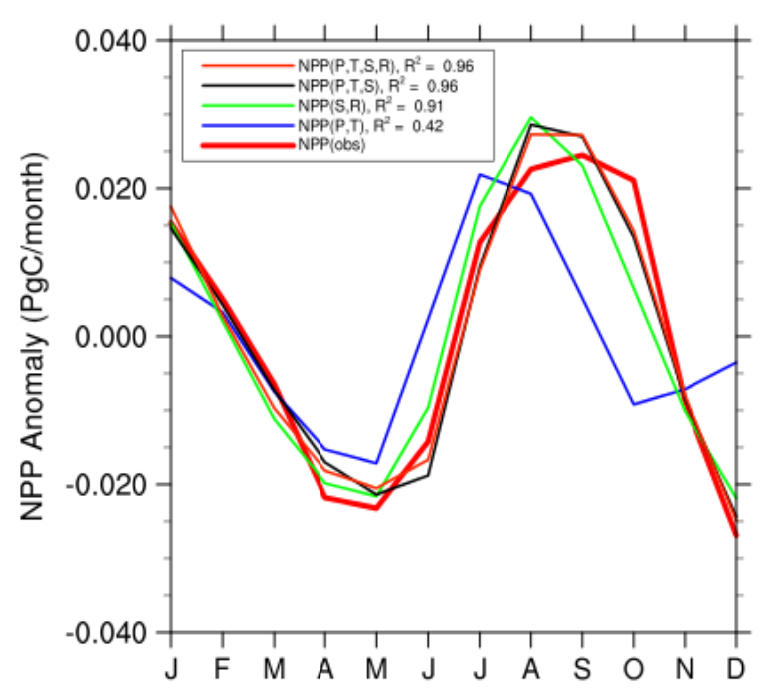

We performed both single variable and multivariate regression analysis (Equation (1)) on the mean seasonal cycle over the period 1982-2006. The correlation coefficients are shown in Table 1 and the averaged seasonal cycle of NPP and the multivariate-generated seasonal cycles are shown in Figure 6 (bottom). We have used only 23 years for the regression analysis because of the uncertainty in soil moisture data for the years 1996 and 1997. We find that the correlation between observed mean seasonal cycle of NPP and the soil water is $0.95\left(\mathrm{R}^{2}=0.90\right)$, thereby indicating a strong control of soil water on the seasonal cycle of NPP. The correlation is relatively lower with the seasonal cycle of precipitation $\left(r=0.52, \mathrm{R}^{2}=0.27\right)$, temperature $\left(\mathrm{r}=0.01, \mathrm{R}^{2}=0.0\right)$ and solar radiation $(\mathrm{r}=-0.63$, $\left.\mathrm{R}^{2}=0.40\right)$. Further, correlation with multivariate seasonal NPP is only $0.65\left(\mathrm{R}^{2}=0.42\right)$ when the independent variables are temperature and precipitation but very large $\left(r=0.95\right.$ to $0.98, R^{2}=0.91$ to 0.96) when soil water is one of the independent variables for the multivariate regression (Figure 6 , Table 1). This suggests that the seasonal cycle of NPP is primarily driven by soil water.

\subsection{NPP in Forest versus Non-Forest Areas}

About $22 \%$ of India's total geographic area is classified as forests, while the rest is classified as non-forest, which includes croplands. While total NPP growth rate is estimated at $3.9 \%$ per decade, forest NPP is estimated to increase at a rate of 3.5\% per decade and non-forest NPP at a faster rate of $4.4 \%$ per decade. Lands used for agricultural activities, including grazing, account for $64 \%$ of India's total geographic area, while only $7.4 \%$ of the land area is used for non-agricultural activities, and the other $6.3 \%$ remains barren [42]. Thus most of the non-forest NPP comes from agriculture and related activities which are heavily managed by humans. Two of the key agriculture management indicators, irrigated area and fertilizer use, are found to be strongly correlated with NPP growth in non-forest areas (Figure 7) - suggesting that observed NPP growth over the non-forested areas are also driven by anthropogenic interventions, such as increases in irrigation area $\left(r=0.77, \mathrm{R}^{2}=0.59\right)$ and fertilizer $\mathrm{use}\left(\mathrm{r}=0.73, \mathrm{R}^{2}=0.53\right)$, in addition to $\mathrm{CO}_{2}$ fertilization. 
Figure 7. Spatial pattern of decadal trends in NPP for (a) forest areas and (b) non-forest areas.Temporal evolution of domain averaged NPP in (c) forest and (d) non-forest areas. Correlation of forest NPP with cumulative afforestation (e), correlation of non-forest NPP with irrigation area (f) and correlation of non-forest NPP with fertilizer consumption in India (g).
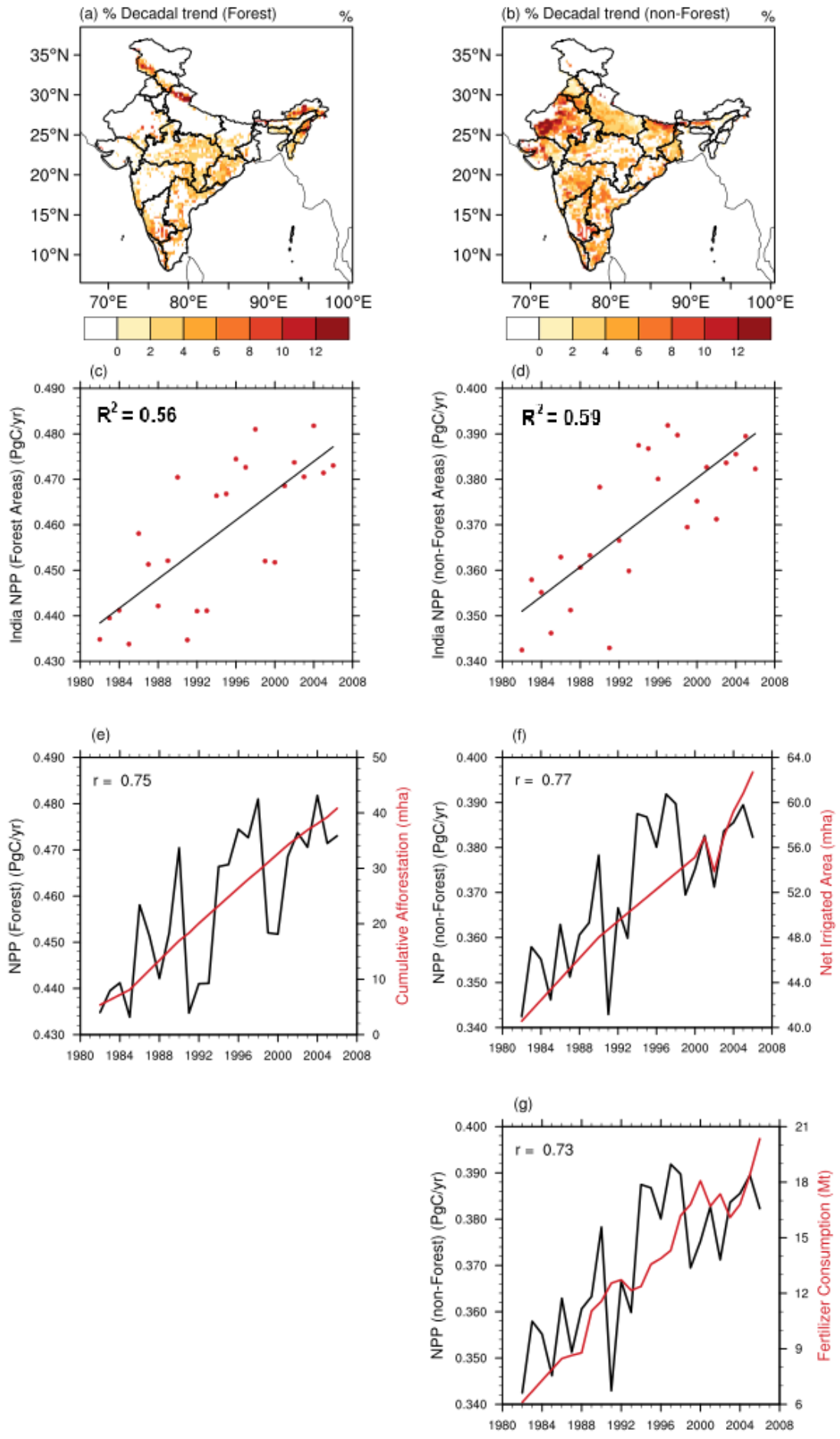

Forested areas are also heavily managed, albeit not as intensely as the non-forest areas. India has been implementing an aggressive afforestation and reforestation program especially since the early 1980s, when large-scale afforestation and reforestation under the social forestry program and later under the Joint Forest Management initiative (1990s) were initiated. The cumulative area planted during the period 1980 to 2005 is estimated to be about 34 million ha (Mha) at an average annual rate 
of 1.32 Mha [28]. Despite the rapid rate of planting, the overall forest area largely remained stable and increased only marginally from 64.20 Mha in 1987 to 67.71 Mha in $2005[43,44]$ because the new plantation programs were taken up in already-existing forests which were either less dense or degraded. This suggests that most of the new plantations were aimed at restoring the degraded forests and increasing the productivity of the existing forests. Therefore, the NPP increase in forest areas is strongly correlated $\left(r=0.75, \mathrm{R}^{2}=0.56\right)$ with the cumulative new plantation area (Figure $7(\mathrm{e})$ ).

\section{Discussion}

One major limitation of the NPP dataset used in this study is the lack of its validation in the region of interest (India). Several studies over the past 10 years have addressed the issue of field validation of LAI and NPP estimates from satellite data. In general, these studies conclude that while LAI can be estimated to within 0.5 LAI units for many biomes (needle leaf forests are an exception), the NPP estimates can deviate from observations by as much as $50 \%$. Observed NPP data are rare, mostly concentrated in mid and high-latitude ecosystems. However, the logic behind NPP estimation is quite robust based on radiation absorption by vegetation canopies. Though data for flux towers is being used to validate NPP estimates, we believe it is still not a direct validation, as flux towers only measure net ecosystem exchange and not NPP. Robust validation of global NPP estimates is challenging because, as in the case of field observations, towers are also located mostly in mid and high-latitude ecosystems. For example, in the case of India, we only know of two towers established recently. The data collected from these towers is still being diagnosed and not yet released to the science community. We intend to use these data once they become available. Furthermore, our analysis here aims to address the interannual variability and trends in NPP and the underlying causes. While the absolute magnitudes are important, the errors associated with them would likely be uniform through the time series.

Another limitation relates to our statistical analysis and evaluation of correlations which cannot establish firm casual relationships. Furthermore, the $\mathrm{R}^{2}$ values and correlations obtained are also small in many cases. This indicates the interplay of multiple variables that exert influence on the terrestrial carbon cycle. Additional sources of uncertainty may arise from the resolution of the data: since the terrestrial ecosystems are very heterogeneous and patchy, $25-\mathrm{km}$ resolution for the NPP product is insufficient to characterize the spatial variations accurately. It is believed that global land observations at the scale of $1 \mathrm{~km}$ would be needed to better understand the terrestrial carbon dynamics. Therefore, our conclusions on attribution of trends and variability require careful observation and modeling evaluation in the future. Specifically, multiple global and regional scale modeling based on detailed process representation and their validation using multiple observations are needed for reaching robust conclusions.

\section{Conclusions}

NPP is an important ecosystem variable which provides a metric for the rate of carbon fixed in the terrestrial ecosystems. It is also an indicator of the health of ecosystems. We used AVHRR-derived NPP [8] to analyze the linear trends and variability over India for the period 1982-2006. For this period, the mean and standard deviation of NPP are estimated at $0.83 \mathrm{PgC} \cdot \mathrm{y}^{-1}$ and $0.03 \mathrm{PgC} \cdot \mathrm{y}^{-1}$, respectively. Our regression analysis shows a linear trend of $3.9 \%$ per decade $(r=0.72$, 
$\mathrm{R}^{2}=0.61$ ) which indicates that the rate of carbon-fixing by terrestrial ecosystems has increased in the past two decades. This result is in close agreement with other recent studies which also found an increasing trend [17,18]. Studies based on long-term observations plots also conclude that observations "over a period of 25 years indicates that the forests are in the process of recuperation, sequestering atmospheric carbon and providing environmental service" [45].

Spatial maps of the trends show large increasing trends in the Western Ghats, Himalayan forests in the north, northeast India, peninsular and central-east India and near-zero or decreasing trends over northern and northwest India. A multivariate linear regression of NPP with temperature, precipitation and global-mean atmospheric $\mathrm{CO}_{2}$ concentration $\left(\mathrm{r}=0.80, \mathrm{R}^{2}=0.64\right)$ indicates that the increasing trend is likely driven by $\mathrm{CO}_{2}$ fertilization of the terrestrial ecosystems. There are many modeling and observational studies in the literature that suggest enhanced carbon uptake due to $\mathrm{CO}_{2}$ fertilization. However, we also find a major influence of irrigation $\left(r=0.77, R^{2}=0.59\right)$ and fertilizer use $\left(r=0.73, R^{2}=0.53\right)$ on the nonforest areas of the country. India initiated a large-scale forest conservation, afforestation and reforestation program starting in the early 1980s. We find that this forest management could have also contributed to the NPP increase over the forested areas in the country $\left(r=0.75, \mathrm{R}^{2}=0.56\right)$.

A multivariate regression of NPP anomaly with anomalies in temperature, precipitation, soil water, solar radiation and global mean $\mathrm{CO}_{2}$ suggests that the interannual variability in NPP is primarily driven by precipitation and temperature variability (Table 1 and Figure 4). In general, we find that the interannual variations in NPP are positively and strongly correlated with precipitation, and negatively but weakly with temperature and global-mean $\mathrm{CO}_{2}$. Mean seasonal NPP is highest during post-monsoon and lowest during the pre-monsoon period. Though climatic conditions (in terms of rainfall, temperature and solar radiation) are most conducive for plant growth during the monsoon period, NPP does not peak during that period. We find that the seasonal maximum of NPP is associated with the seasonal maximum of soil moisture that occurs during the post-monsoon period. This indicates the dominant role of soil moisture for vegetation productivity. Our multivariate regression analysis shows a strong correlation of $0.95\left(\mathrm{R}^{2}=0.91\right)$ between observed seasonal cycle of NPP and multivariate NPP that is generated using soil water content and solar radiation as independent variables.

\section{Acknowledgments}

We thank the funding from Department of Science and Technology under the grant DST0948. Rajiv K. Chaturvedi is supported by the Ministry of Environment and Forests through National Environmental Sciences Fellowship. Hosahalli V. Gangamani is supported by the Divecha Center for Climate Change.

\section{References}

1. Roy, J.; Saugier, B.; Mooney, H.A.Terrestrial Global Productivity; Academic Press: London, UK, 2001; p. 557.

2. Veroustraete, F.; Sabbe, H.; Eerens, H. Estimation of carbon mass fluxes over Europe using the C-Fix model and Euroflux data. Remote Sens. Environ. 2002, 83, 376-399. 
3. Field, C.B.; Randerson, J.T.; Malmstrom, C.M. Global net primary production-Combining ecology and remote-sensing.Remote Sens. Environ. 1995, 51, 74-88.

4. Prince, S.D.; Goward, S.N. Global primary production: A remote sensing approach. J. Biogeogr. 1995, 22, 815-835.

5. Knorr, W.; Heimann, M. Impact of drought stress and other factors on seasonal land biosphere $\mathrm{CO}_{2}$ exchange studied through an atmospheric tracer transport model. Tellus $B$ 1995, 47, 471-489.

6. Ruimy, A.; Dedieu, G.; Saugier, B. TURC: A diagnostic model of continental gross primary productivity and net primary productivity. Glob. Biogeochem.Cy. 1996, 10, 269-285.

7. Zhao, M.S.; Heinsch, F.A.; Nemani, R.R.; Running, S.W. Improvements of the MODIS terrestrial gross and net primary production global data set. Remote Sens. Environ. 2005, 95, 164-176.

8. Nemani, R.R.; Keeling, C.D.; Hashimoto, H.; Jolly, W.M.; Piper, S.C.; Tucker, C.J.; Myneni, R.B.; Running, S.W. Climate-driven increases in global terrestrial net primary production from 1982 to 1999. Science 2003, 300, 1560-1563.

9. Running, S.; Nemani, R.; Heinsch, F.A.; Zhao, M.; Reeves, M.; Hashimoto, H. A continuous satellite-derived measure of global terrestrial primary productivity: Future science and applications. Bioscience 2004, 56, 547-560.

10. Knorr, W.; Heimann, M. Uncertainties in global terrestrial biosphere modeling 1-A comprehensive sensitivity analysis with a new photosynthesis and energy balance scheme. Glob. Biogeochem. Cy. 2001, 15, 207-225.

11. Cao, M.; Prince, S.D.; Small, J.; Goetz, S.J. Remotely Sensed Interannual Variations and Trends in Terrestrial Net Primary Productivity 1981-2000. Ecosystems 2004, 7, 233-242.

12. Zhao, M.S.; Running, S.W. Drought-induced reduction in global terrestrial net primary production from 2000 through 2009. Science 2010, 329, 940-943.

13. Hingane, L.S.Some aspects of carbon-dioxide exchange between atmosphere and indian plant biota. Clim. Change 1991, 18, 425-435.

14. Dadhwal, V.K.; Nayak, R.K. A preliminary estimate of bio- geochmeical cycle of carbon for India. Sci. Cult. 1993, 59, 9-13.

15. Chhabra, A.; Dadhwal, V.K. Estimating terrestrial net primary productivity over India using satellite data. Curr. Sci. India 2004, 86, 269-271.

16. Nayak, R.K.; Patel, N.R.; Dadhwal, V.K. Estimation and analysis of terrestrial net primary productivity over India by remote-sensing-driven terrestrial biosphere model. Environ. Monit. Assess. 2010, 170, 195-213.

17. Singh, R.P.; Rovshan, S.; Goroshi, S.K.; Panigrahy, S.; Parihar, J.S. Spatial and temporal variability of Net Primary Productivity (NPP) over terrestrial biosphere of India using NOAA-AVHRR based GloPEM model. J. Ind. Soc. Remote Sens. 2011, 39, 345-353.

18. Nayak, R.K.; Patel, N.R.; Dadhwal, V.K. Inter-annual variability and climate control of terrestrial net primary productivity over India. Int. J. Climatol. 2012, doi: 10.1002/joc.3414.

19. Tucker, C.J.; Pinzon, J.E.; Brown, M.E.; Slayback, D.A.; Pak, E.W.; Mahoney, R.; Vermote, E.F.; El Saleous, N. An extended AVHRR 8-km NDVI dataset compatible with MODIS and SPOT vegetation NDVI data. Int. J. Remote Sens. 2005, 26, 4485-4498. 
20. Myneni, R.B.; Nemani, R.R.; Running, S.W. Estimation of global leaf area index and absorbed par using radiative transfer models.IEEE Trans. Geosci. Remote Sens. 1997, 35, 1380-1393.

21. Milesi, C.; Samanta, A.; Hashimoto, H.; Kumar, K.K.; Ganguly, S.; Thenkabail, P.S.; Srivastava, A.N.; Nemani, R.R.; Myneni, R.B. Decadal variations in NDVI and food production in India. Remote Sens. 2010, 2, 758-776.

22. Kariyeva, J.; van Leeuwen, W.J.D. Environmental drivers of NDVI-based vegetation phenology in Central Asia. Remote Sens. 2011, 3, 203-246.

23. Li, Z.Q.; Guo, X.L. Detecting climate effects on vegetation in northern mixed prairie using NOAA AVHRR 1-km time-series NDVI data. Remote Sens. 2012, 4, 120-134.

24. Yin, H.; Udelhoven, T.; Fensholt, R.; Pflugmacher, D.; Hostert, P. How Normalized Difference Vegetation Index (NDVI) trends from Advanced Very High Resolution Radiometer (AVHRR) and Système Probatoire d'Observation de la Terre VEGETATION (SPOT VGT) time series differ in agricultural areas: An Inner Mongolian case study. Remote Sens. 2012, 4, 3364-3389.

25. Heinsch, F.A.; Zhao, M.; Running, S.W.; Kimball, J.S.; Nemani, R.R.; Davis, K.J.; Bolstad, P.V.; Cook, B.D.; Desai, A.R.; Ricciuto, D.M.; et al. Evaluation of remote sensing based terrestrial productivity from MODIS using regional tower eddy flux network observations. IEEE Trans. Geosci. Remote Sens. 2006, 44, 1908-1925.

26. Turner, D.P.; Ritts, W.D.; Cohen, W.B.; Gower, S.T.; Running, S.W.; Zhao, M. Costa, M.H.; Kirschbaum, A.A.; Ham, J.M.; Saleska, S.R.; et al. Evaluation of MODIS NPP and GPP products across multiple biomes. Remote Sens. Environ. 2006, 102, 282-292.

27. Gebremichael, M.; Barros, A.P. Evaluation of MODIS gross primary productivity (GPP) in tropical monsoon regions. Remote Sens. Environ. 2006, 100, 150-166.

28. Ravindranath, N.H.; Chaturvedi, R.K.; Murthy, I.K. Forest conservation, afforestation and reforestation in India: Implications for forest carbon stocks. Curr. Sci. India 2008, 95, 216-222.

29. Owensby, C.E.; Ham, J.M.; Knapp, A.K.; Auen, L.M. Biomass production and species composition change in a tallgrass prairie ecosystem after long-term exposure to elevated atmospheric $\mathrm{CO}_{2}$. Glob. Change Biol. 1999, 5, 497-506.

30. Prentice, I.C.; Farquhar, G.D.; Fasham, M.J.R.; Goulden, M.L.; Heimann, M.; Jaramillo, V.J.; Kheshgi, H.S.; Le Quere, C.; Scholes, R.J.; Wallac, D.W.R. The Carbon Cycle and Atmospheric Carbon Dioxide. In Climate Change 2001: The Scientific Basis; Houghton, J.T., Ding, Y., Griggs, D.J., Noguer, M., van der Linden, P.J., Dai, A., Maskell, K., Johnson, C.A., Eds.; Cambridge University Press: New York, NY, USA, 2001.

31. Norby, R.J.; Delucia, E.H.; Gielen, B.; Calfapietra, C.; Giardina, C.P.; King, J.S.; Ledford, J.; McCarthy, H.R.; Moore, D.J.; Ceulemans, R.; et al. Forest response to elevated $\mathrm{CO}_{2}$ is conserved across a broad range of productivity. Proc. Natl. Acad. Sci. USA 2005, 102, 18052-18056.

32. Gedalof, Z.; Berg, A.A. Tree ring evidence for limited direct $\mathrm{CO}_{2}$ fertilization of forests over the 20th century. Glob. Biogeochem. Cy. 2010, 24, doi: 10.1029/2009GB003699.

33. Friedlingstein, P.; Cox, P.M.; Betts, R.A.; Bopp, L.; von Bloh, W.; Brovkin, V.; Cadule, P.; Doney, S.C.; Eby, M.; Fung, I.Y.; et al. Climate-carbon cycle feedback analysis: Results from the (CMIP)-M-4 model intercomparison. J. Climate 2006, 19, 3337-3353.

34. Bala, G.; Caldeira, K.; Mirin, A.; Wickett, M.; Delire, C.; Phillips, T.J. Biogeophysical effects of $\mathrm{CO}_{2}$ fertilization on global climate. Tellus B 2006, 58, 620-627. 
35. Govindasamy, B.; Thompson, S.; Mirin, A.; Wickett, M.; Caldeira, K.; Delire, C. Increase of carbon cycle feedback with climate sensitivity: results from a coupled climate and carbon cycle model. Tellus B 2005, 57, 153-163.

36. Thompson, S.L.; Govindasamy, B.; Mirin, A.; Caldeira, K.; Delire, C.; Milovich, J.; Wickett, M.; Erickson, D. Quantifying the effects of $\mathrm{CO} 2$-fertilized vegetation on future global climate and carbon dynamics. Geophys. Res. Lett. 2004, 31, L23211.

37. Bala, G.; Gopalakrishnan, R.; Jayaraman, M.; Nemani, R.; Ravindranath, N.H. $\mathrm{CO}_{2}$-fertilization and potential future terrestrial carbon uptake in India. Mitig. Adapt. Strat. Gl. 2011, 16, 143-160.

38. IPCC. Climate Change 2007: The Physical Science Basis; Cambridge University Press: Cambridge, UK/New York, NY, USA, 2007.

39. Le Quere, C.; Raupach, M.R.; Canadell, J.G.; Marland, G.; Bopp. L.; Ciasis, P.; Conway, T.J.; Doney, S.C.; Felly, R.A.; Foster, P.; et al. Trends in the sources and sinks of carbon dioxide. Nat. Geosci. 2009, 2, 831-836.

40. Tian, H.Q.; Melillo, J.M.; Kicklighter, D.W.; Pan, S.F.; Liu, J.Y.; McGuire, A.D.; Moore, B. Regional carbon dynamics in monsoon Asia and its implications for the global carbon cycle. Global Planet. Change 2003, 37, 201-217.

41. Wolter, K.; Timlin, M.S. Measuring the strength of ENSO events: How does 1997/98 rank? Weather 1998, 53, 315-324.

42. Agricultural Statistics at a Glance-2000Report; Directorate of Economics and Statistics, Ministry of Agriculture, Government of India: New Delhi, India, 2000.

43. FSI State of Forest Report-2005Report; Ministry of Environment and Forests, Government of India: Dehradun, India, 2007.

44. FSI State of Forest Report-1987Report; Ministry of Environment and Forests, Government of India: Dehradun, India, 1989.

45. Bhat, D.M.; Ravindranath, N.H. Aboveground standing biomass and carbon stock dynamics under a varied degree of anthropogenic pressure in tropical fain forests of Uttara Kannada District, Western Ghats, India. Taiwania 2011, 56, 85-96.

(C) 2013 by the authors; licensee MDPI, Basel, Switzerland. This article is an open access article distributed under the terms and conditions of the Creative Commons Attribution license (http://creativecommons.org/licenses/by/3.0/). 